\title{
Role of estrogen receptor (ER) $\alpha$ in insulin-like growth factor (IGF)-I-induced responses in MCF-7 breast cancer cells
}

\author{
S Zhang ${ }^{1}, \mathbf{X ~ L i}{ }^{1}$, R Burghardt' ${ }^{2}$ R Smith III ${ }^{3}$ and S H Safe ${ }^{1,4}$ \\ ${ }^{1}$ Department of Veterinary Physiology and Pharmacology, ${ }^{2}$ Department of Veterinary Anatomy and Public Health, ${ }^{3}$ Department of Veterinary Pathobiology, Texas A\&M \\ University, College Station, TX 77843, USA \\ ${ }^{4}$ Institute of Biosciences and Technology, Texas A\&M University System Health Science Center, 2121 West Holcombe Boulevard, Houston, TX 77030, USA \\ (Requests for offprints should be addressed to S H Safe, Department of Veterinary Physiology \& Pharmacology, Texas A\&M University, 4466 TAMU, College Station, \\ TX 77843-4466, USA; Email: ssafe@cvm.tamu.edu)
}

\begin{abstract}
Insulin-like growth factor-I (IGF-I) is a mitogenic polypeptide that induces proliferation of MCF-7 breast cancer cells, and cotreatment with the phosphoinositide 3-kinase (PI3-K) inhibitor LY294002 and the antiestrogen ICI 182780 inhibits IGF-I-induced growth. The role of estrogen receptor $\alpha(E R \alpha)$ in mediating responses induced by IGF-I was investigated in cells transfected with small inhibitory RNA for ER $\alpha$ (iER $\alpha$ ). The results showed that IGF-I-dependent phosphorylation of Akt and mitogen-activated protein kinase, induction of $\mathrm{G}_{1}-\mathrm{S}$-phase progression and enhanced expression of cyclin D1 and cyclin E were dependent on ER $\alpha$. Moreover, these same IGF-I-induced responses were also inhibited by the antiestrogen $\mathrm{ICI} 182780$ and this was in contrast to a previous report suggesting that $\mathrm{ICl} 182780$ did not affect IGF-I-dependent activation of PI3-K or induction of cyclin D1 expression. ICI 182780 exhibits antimitogenic activity and $\mathrm{iER} \alpha$ inhibits $\mathrm{G}_{1}-\mathrm{S}$-phase progression and proliferation of MCF-7 cells treated with IGF-I, suggesting that the effects of the antiestrogen are primarily related to downregulation of ER $\alpha$.
\end{abstract}

Journal of Molecular Endocrinology (2005) 35, 433-447

\section{Introduction}

Insulin-like growth factors (IGFs) are mitogenic polypeptides that play an important role in growth, differentiation and survival of normal cells as well as proliferation of tumor cells (Dickson \& Lippman 1995, Gullick et al. 1998, Grimberg \& Cohen 2000, Singh 2000, Yee \& Lee 2000). IGFs can act in an autocrine or paracrine fashion through interaction with the membrane-bound IGF receptor (IGFR). IGF-dependent signaling is regulated at multiple levels including their interaction with IGF-binding proteins, which dramatically modulate the activity and function of these mitogens (Grimberg \& Gohen 2000). IGF signaling pathways are important for growth of multiple cancers, and elevated serum IGF-I levels are associated with an increased risk of prostate and colon cancers (Chan et al. 1998, Cohen 1998, Wolk et al. 1998, Ma et al. 1999).

The mitogenic activity of IGF-I and interactions between growth factor and estrogen receptor (ER) signaling has been investigated extensively in breast cancer cells, and estradiol $\left(\mathrm{E}_{2}\right)$ and IGF-I induce many of the same responses in these cell lines (Dickson \& Lippman 1995, Smith 1998, Weigel \& Zhang 1998, Kato et al. 2000, Yee \& Lee 2000, Luconi et al. 2002, Segars \& Driggers 2002). For example, IGF-I and $\mathrm{E}_{2}$ induce proliferation of ER-positive breast cancer cell lines and several genes, including $\mathrm{pS} 2$, cathepsin $\mathrm{D}$, cyclin D1, the progesterone receptor and IGF-IR, are also induced by $\mathrm{E}_{2}$ and IGF-I (Cavailles et al. 1989, Wakeling et al. 1989, Katzenellenbogen \& Norman 1990, Chalbos et al. 1993, Ignar-Trowbridge et al. 1993, Westley \& May 1994, Martin et al. 2000, Oesterreich et al. 2001, Varma \& Conrad 2002). The estrogen-like activity of IGF-I, transforming growth factor $\alpha$ (TGF $\alpha)$ and epidermal growth factor (EGF) are due, in part, to growth factor-induced phosphorylation of ER which in turn activates ER-dependent genes in the absence of $\mathrm{E}_{2}$ (Ali et al. 1993, Kato et al. 1995, 2000, Bunone et al. 1996, Ignar-Trowbridge et al. 1996, Joel et al. 1998, Smith 1998, Weigel \& Zhang 1998, Luconi et al. 2002). $\mathrm{E}_{2}$ also exhibits growth factor-like activity and the rapid non-genomic actions of estrogens (Watson et al. 1998, 2002, Levin 2002) depend, in part, on extranuclear ER and its association with several proteins involved in kinase signaling pathways. For example, ER $\alpha$ directly interacts with the $\mathrm{SH} 2$ region of Src, the p85a regulatory subunit of phosphoinositide 3-kinase (PI3-K), caveolins, $\mathrm{G \alpha}_{\mathrm{I}}$ (a G protein), Shc and IGF-IR (Kahlert et al. 2000, Migliaccio et al. 2000, Simoncini et al. 2000, Sun et al. 2001, Wyckoff et al. 2001, Razandi et al. 2002, Song et al. 2002). The functional significance of these 
interactions may be cell-context-dependent. For example, antibodies that block IGF-IR signaling by IGF-I did not inhibit activation of the mitogen-activated protein kinase (MAPK) pathway by $\mathrm{E}_{2}$ in MCF-7 cells (Duan et al. 2001).

Research in our laboratory has concentrated on the mechanism of IGF-I-ER $\alpha$ crosstalk in breast cancer cells (Wang et al. 2000, Castro-Rivera et al. 2001, Duan et al. 2001, Xie et al. 2001, Qin et al. 2002, Ngwenya \& Safe 2003), and this report describes our research on the role of $\mathrm{ER} \alpha$ in mediating IGF-I-induced responses in MCF-7 cells. Transfection of small interfering RNA (siRNA) for $\mathrm{ER} \alpha(\mathrm{iER} \alpha)$ into MCF-7 cells resulted in decreased $\mathrm{ER} \alpha$ protein, and this was accompanied by decreased phosphorylation of MAPK and decreased PI3-Kdependent phosphorylation of Akt. In addition, loss of $\mathrm{ER} \alpha$ also resulted in decreased IGF-I-induced $\mathrm{G}_{1}-\mathrm{S}$ phase progression and expression of proteins associated with cell-cycle progression such as cyclin D1 and cyclin E. In contrast to a recent report (Varma \& Conrad 2002), ICI 182780 not only inhibited MCF-7 cell proliferation but also decreased IGF-I-induced kinase signaling and cyclin D1 and cyclin E expression in MCF-7 cells, and this was correlated with downregulation of ER $\alpha$. We also investigated the role of insulin receptor substrate-I (IRS-I) in mediating IGF-I-induced activation of MAPK and PI3-K pathways using siRNA for IRS-I (iIRS-I), which effectively knocks down IRS-I. The results show that IRS-I is not required for kinase activation by IGF-I. These results clearly demonstrated that IGF-I-dependent mitogenic activity in breast cancer cells is dependent on $\mathrm{ER} \alpha$ and this is consistent with the estrogen-like activity of IGF-I in breast cancer cells.

\section{Materials and methods}

\section{Chemicals, cells, antibodies, oligonucleotides, and plasmids}

MCF-7 cells were obtained from the American Type Culture Collection (ATCG, Manassas, VA, USA). Dulbecco's modified Eagle's medium (DMEM)/Ham's F-12 (DMEM/F-12) with and without Phenol Red, $100 \times$ antibiotic/antimycotic solution, propidium idodide, $\mathrm{E}_{2}$ and human recombinant IGF-I were purchased from Sigma (St Louis, MO, USA). Fetal bovine serum was purchased from Intergen (Purchase, NY, USA). $\left[\gamma^{-32} \mathrm{P}\right]$ ATP $(300 \mathrm{Ci} / \mathrm{mmol})$ was obtained from PerkinElmer Life Sciences. Poly (dI-dC) and T4 polynucleotide kinase were purchased from Roche Molecular Biochemicals (Indianapolis, IN, USA). Antibodies for lamin $\mathrm{A} / \mathrm{C}, \mathrm{ER} \alpha, \mathrm{pAKT}$, and pERK proteins were obtained from Santa Cruz Biotechnology (Santa Cruz, CA, USA). Antibodies for GAPDH was obtained from Ambion (Austin, TX, USA). Human ER $\alpha$ expression plasmid was provided by Dr Ming-Jer Tsai (Baylor College of
Medicine, Houston, TX, USA). Lysis buffer, luciferase reagent and RNase were obtained from Promega Corp. (Madision, WI, USA). PD98059 and LY294002 were purchased from Calbiochem (San Diego, CA, USA). ICI 182780 was provided by Dr Alan Wakeling (Zeneca Pharmaceuticals, Macclesfield, UK), and 2,3,7,8tetrachlorodibenzo- $p$-dioxin (TCDD; $>98 \%$ ) was prepared in this laboratory.

The pSRF construct containing five tandem serumresponse factor (SRF) elements linked to a luciferase reporter gene was purchased from Stratagene (La Jolla, CA, USA), and the GAL4-ElkC plasmid was provided by Roger Treisman (Imperial Cancer Research Centre, London, UK). The $\mathrm{pDRE}_{3}$-luc construct containing three tandem consensus dioxin-responsive elements (DREs) was prepared in this laboratory and the $\mathrm{E}_{2}$-responsive pC3-luc construct was provided by $\mathrm{Dr}$ Donald McDonnell (Duke University, Durham, NG, USA). DMSO was used as solvent for $\mathrm{E}_{2}$ and the antiestrogens. Acetic acid $(0 \cdot 1 \mathrm{M})$ was used as solvent for IGF-I. The siRNAs for GL2, lamin A/C and ER $\alpha$ were prepared by Xeragon (Germantown, MD, USA), and the sequences of iRNA duplexes were indicated as follows: GL2, 5'-GGUAGGGGGAAUACUUGGATT3', 3'-TTGCAUGCGCGUUAUGAAGCU-5'; lamin A/C, 5'-CUGGACUUCGAGAAGAACATT-3', 3'TTGACGUGAAGGUCUUCUUGU- $5^{\prime} ; \quad$ ER $\alpha$, 5'AGGCUCAUUCGAGCAACAGTT-3', 3'-TTUCGG AGUAAGGUGGGUGUC-5'. The siRNA for IRS-I was comprised of four pooled siRNA duplexes (catalogue number M-003015) from Dharmacon (Lafayette, CO, USA).

\section{Cell-proliferation assay}

MCF-7 cells were seeded in DMEM/F-12 with 2.5\% stripped fetal bovine serum and treated with different factors for 9 days. Cell numbers were determined using a Coulter $\mathrm{Zl}$ counter, and results for each treatment are given as means \pm S.D. from at least three different determinations for each treatment group. For the cell-proliferation study involving siRNA, cells were transfected with iER $\alpha$ or siRNA for GL2 (iGL2) and, after $24 \mathrm{~h}$, treated with $10 \mathrm{nM}$ IGF-I for $48 \mathrm{~h}$. Cell numbers were then determined.

\section{Transfection of MCF-7 cells}

Cells were cultured in six-well plates in $2 \mathrm{ml}$ DMEM/F-12 supplemented with 5\% fetal bovine serum. After $16-20 \mathrm{~h}$ when cells were $30-50 \%$ confluent, siRNA duplexes and/or reporter gene constructs were transfected using Oligofectamine Reagent (Invitrogen, Carlsbad, CA, USA). For each well of a six-well plate, $0 \cdot 2 \mu \mathrm{mol}$ iRNA duplex was transfected. Cells were harvested $36-44 \mathrm{~h}$ after transfection by 
manual scraping in $1 \times$ lysis buffer (Promega). For whole-cell lysates, cells were frozen and thawed in liquid nitrogen, vortexed for $30 \mathrm{~s}$, and centrifuged at $12000 \boldsymbol{g}$ for $1 \mathrm{~min}$. Lysates were assayed for luciferase activity using luciferase assay reagent (Promega). $\beta$-Galactosidase activity was measured using Tropix Galacto-Light Plus assay system (Tropix, Bedford, MA, USA) in a Lumicount microwell plate reader (Packard Instrument Co.).

\section{Preparation of nuclear extracts}

MCF-7 cells were seeded in a $100 \mathrm{~mm}$ tissue culture dish (Becton Dickinson Labware, Franklin Lakes, NJ, USA) in DMEM/F-12 with $2 \cdot 5 \%$ dextran/charcoal-stripped fetal bovine serum. After $24 \mathrm{~h}$, cells were washed twice in PBS, scraped in $1 \mathrm{ml}$ HEGD buffer ( $25 \mathrm{mM}$ Hepes, $1.5 \mathrm{mM}$ EDTA, $1 \mathrm{mM}$ dithiothreitol and $10 \%$ (v/v) glycerol, $\mathrm{pH} 7 \cdot 6$ ) and homogenized. The cellular homogenate was centrifuged for $5 \mathrm{~min}$ at $1000 \mathrm{~g}$. The supernatant was discarded and the pellet was suspended in $200 \mathrm{ml}$ HEGDK (HEGD with $0.5 \mathrm{M} \mathrm{KCl}$ ) and incubated on ice for $15 \mathrm{~min}$ with frequent vortexing. Samples were centrifuged at $14000 \mathrm{~g}$ for $1 \mathrm{~min}$, and nuclear protein concentration in the supernatant was determined by Bradford assay (Bradford 1976). The supernatant was stored in small aliquots at $-80^{\circ} \mathrm{C}$ for further use.

\section{Western immunoblot analysis}

An aliquot of whole-cell lysate containing $30 \mu \mathrm{g}$ protein was diluted with loading buffer, boiled and loaded on a $10 \%$ SDS/polyacrylamide gel. Samples were electrophoresed at $150-180 \mathrm{~V}$ for 3-4 h, and separated proteins were transferred to polyvinylidene difluoride (PVDF) membrane (Bio-Rad, Hercules, CA, USA) in buffer containing $48 \mathrm{mM}$ Tris/HCl, $29 \mathrm{mM}$ glycine and $0 \cdot 025 \%$ SDS. Proteins were detected by incubation with polyclonal primary antibodies for lamin A/C, ER $\alpha$ H184, GAPDH, p-AKT1/2/3-Ser473 and p-ERK (1:1000 dilution) followed by blotting with horseradish peroxidase-conjugated anti-rabbit (for $\mathrm{ER} \alpha$ and p-AKT), anti-goat (for lamin $\mathrm{A} / \mathrm{C}$ ) or anti-mouse (for GAPDH and p-ERK) secondary antibody (1:5000 dilution). Blots were then exposed to chemiluminescent substrate (PerkinElmer Life Sciences) and placed in Kodak X-Omat AR autoradiography film. Band intensities were determined by a scanning laser densitometer (Sharp Electronics Corp., Mahwah, NJ, USA) using Zero-D Scanalytics software (Scanalytics Corp., Billerica, MA, USA).

\section{FACS analysis}

Cells were transfected with iER $\alpha$ or iGL2. After 20-24 h cells were treated with $0 \cdot 1 \mathrm{M}$ acetic acid or $10 \mathrm{nM}$ IGF (acetic acid as a vehicle) for $18-20 \mathrm{~h}$ in serum-free medium. Cells were then trypsinized, and $\sim 2 \times 10^{6}$ cells were centrifuged and resuspended in $1 \mathrm{ml}$ staining solution $(50 \mu \mathrm{g} / \mathrm{ml}$ propidium iodide (PI), $4 \mathrm{mM}$ sodium citrate, 30 units $/ \mathrm{ml}$ RNase and $0 \cdot 1 \%$ Triton X-100, $\mathrm{pH} 7 \cdot 8$ ). Cells were then incubated at $37^{\circ} \mathrm{C}$ for $10 \mathrm{~min}$, and prior to FACS analysis, $\mathrm{NaCl}$ was added to give a final concentration of $0 \cdot 15 \mathrm{M}$. Cells were analyzed on a FACS Calibur flow cytometer (BD PharMingen) using CellQuest acquisition software (BD PharMingen). PI fluorescence was collected through a 585/542 nm bandpass filter, and list mode data were acquired on a minimum of 12000 single cells defined by a dot plot of PI width versus PI area. Data analysis was performed in ModFit LT (Verity Software House, Topsham, ME, USA) using PI width versus PI area to exclude cell aggregates. FlowJo (Treestar, Palo Alto, CA, USA) was used to generate plots shown in the figures.

\section{Gel electrophoretic mobility shift assay (EMSA)}

The probe containing a consensus estrogen-responsive element (ERE; 5'-GTCGAAAGTCAGGTCACAGTG ACGTGATCAAAGTT-3') was synthesized, annealed and ${ }^{32} \mathrm{P}$-labeled at the $5^{\prime}$-end using $\mathrm{T} 4$ polynucleotide kinase (Roche) and $\left[\gamma_{-}{ }^{32} \mathrm{P}\right] \mathrm{ATP}$. The binding reactions were performed on ice. For each lane, an appropriate amount of HEGDK buffer was added to $5 \mu \mathrm{g}$ MCF-7 cell nuclear extracts to bring the total volume to $5 \mu$ l. HEGD buffer $(15 \mu \mathrm{l})$ was added to dilute the salt concentration and $1 \mu \mathrm{g}$ poly $(\mathrm{dI}-\mathrm{dC})$ was used to block the non-specific binding. After incubation for $5 \mathrm{~min}$, $0.01 \mathrm{pmol}$ radio-labeled probe was added and incubated for $10 \mathrm{~min}$. ER antibody (sc-7202; Santa Cruz Biotechnology) was then added to the mixture and incubated for another $5 \mathrm{~min}$ if applicable. The mixture was resolved on 5\% non-denaturing PAGE and protein-DNA complexes were visualized using Storm Imager system (Molecular Dynamics, Sunnyvale, CA, USA).

\section{Immunostaining}

MCF-7 cells were seeded in DMEM/F-12 with 2.5\% dextran/charcoal-stripped fetal bovine serum in twowell Lab-Tek chamber slides (Nalge Nunc International Corp., Naperville, IL, USA). In experiments involving siRNAs, after $24 \mathrm{~h}$ cells were transfected with siRNA for lamin A/C (iLMN) or iER $\alpha$ with Oligofectamine according to manufacturer's recommendation and incubated for $48 \mathrm{~h}$ before methanol fixation. Otherwise, cells were directly treated and fixed. Cells were fixed in methanol at $-20{ }^{\circ} \mathrm{C}$ for $10 \mathrm{~min}$. Slides were air-dried, washed in PBS $/ 0.3 \%$ Tween-20 for $10 \mathrm{~min}$, and blocked with 1:20 goat serum in antibody dilution buffer (1\% BSA, PBS, $0 \cdot 3 \%$ Tween-20 and $31 \%$ glycerol with 

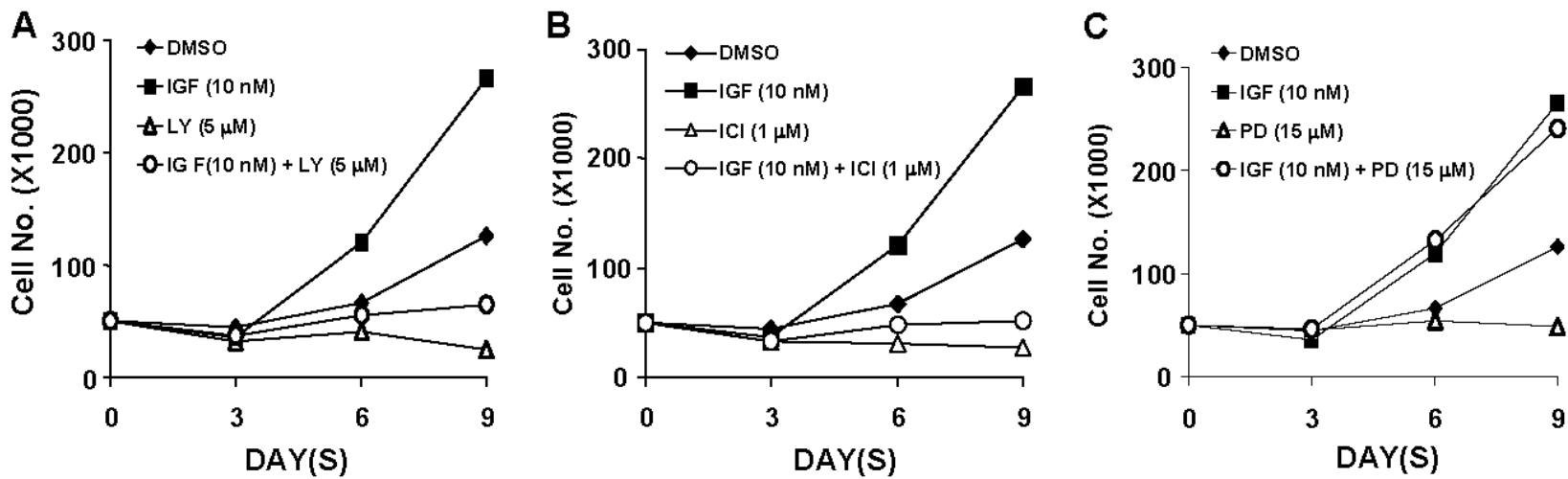

Figure 1 IGF-I-induced proliferation of MCF-7 cells and interactions with LY294002 (LY; A), ICI 182780 (ICl; B), and PD98059 (PD; C). MCF-7 cells were seeded in six-well plates and treated with $10 \mathrm{nM} \mathrm{IGF-I} \mathrm{and/or} 1,5$, or $15 \mu \mathrm{M}$ of the different chemicals for 9 days, and cell numbers were determined as described in the Materials and methods. Results from the experiments are given as means \pm S.D. from at least three different determinations for each treatment group. IGF-I significantly $(P<0.05)$ increased growth (compared with solvent control) and only ICI 182780 and LY294002 significantly decreased IGF-I-induced proliferation.

$\left.0.5 \mathrm{M} \mathrm{Na} \mathrm{NaO}_{3}, \mathrm{pH} 9 \cdot 5\right)$ for $1 \mathrm{~h}$ in a humidified chamber. ER antibody (sc-7202) in antibody dilution buffer (1:100 dilution) was added and incubated in a humidified chamber at $4{ }^{\circ} \mathrm{C}$ for overnight. Slides were washed three times, every $20 \mathrm{~min}$ in PBS/0.3\% Tween20, and then probed with FITC-conjugated anti-rabbit IgG antibody (sc-2012; Santa Cruz Biotechnology) in antibody dilution buffer (1:1000 dilution) for $2 \mathrm{~h}$. Slides were then washed for $30 \mathrm{~min}$ (three times) in PBS/ $0 \cdot 3 \%$ Tween-20 and then in deionized water for $15 \mathrm{~min}$ and mounted in Vectashield mounting medium (Vector Laboratories, Burlingame, CA, USA). Immunostaining was observed with a Zeiss Axioplan2 microscope fitted with a Hamamatsu-C5810 chilled 3 CCD color camera.

\section{Statistical analysis}

Statistical significance was determined by analysis of variance and Scheffe's test, and the levels of probability are noted. The results are expressed as means \pm S.D. from at least three separate (replicate) experiments for each treatment group.

\section{Results}

\section{Mitogenic activity of IGF-I}

The mitogenic activity of IGF-I was initially investigated in MCF-7 cells and the results in (Fig. 1) show that treatment with $10 \mathrm{nM}$ IGF significantly induced proliferation of these cells. Treatment of MCF-7 cells with $5 \mu \mathrm{M}$ LY294009, $15 \mu \mathrm{M}$ PD98059, and $1 \mu \mathrm{M}$ ICI 182780 also significantly inhibited MCF-7 cell growth compared with solvent (DMSO)-treated controls. How- ever, in cells cotreated with IGF-I plus these inhibitors, growth factor-induced proliferation of MCF-7 cells was inhibited by LY294002 and ICI 182780 but not PD98059. These results are consistent with previous reports on the effects of LY294002 and ICI 182780 on IGF-I induced growth (Wakeling et al. 1989, Dufourny et al. 1997, Oesterreich et al. 2001, Varma \& Conrad 2002) and suggest a role for PI3-K and ER $\alpha$ in mediating the mitogenic activity of IGF-I.

\section{IGF-I-induced responses are dependent on ER $\alpha$ : effects of iER $\alpha$}

The role of ER $\alpha$ in mediating IGF-I-induced proliferation and gene activation was further investigated in MCF-7 cells using RNA interference with iER $\alpha$. Whole-cell lysates from MCF-7 cells transfected with iER $\alpha$ or iLMN (non-specific control) and untransfected cells were analyzed by western blot analysis (Fig. 2A). iER $\alpha$ specifically induced downregulation of ER $\alpha$ but not LMN (non-specific) protein, whereas iLMN decreased iLMN but not ER $\alpha$ protein. Over several studies, transfected iER $\alpha$ decreased ER $\alpha$ protein by $>50 \%$ in whole-cell lysates and this is consistent with the high transfection efficiencies observed in MCF-7 cells. iER $\alpha$-mediated decreases in nuclear $\operatorname{ER} \alpha$ were confirmed in a gel mobility shift assay with nuclear extracts from MCF-7 cells and [ $\left.{ }^{32} \mathrm{P}\right]$ ERE (Fig. 2B). The intensity of the specifically bound retarded ER $\alpha$-ERE band (Fig. 2B, lane 3), was decreased in cells transfected with iER $\alpha$ (Fig. 2B, lane 4) or after incubation with excess unlabeled ERE (Fig. 2B, lane 2). Extracts from cells transfected with iLMN did not affect retarded band intensity (Fig. 2B, lane 5) and ER $\alpha$ antibodies supershifted the specifically bound band (Fig. 2B, lane 1). 


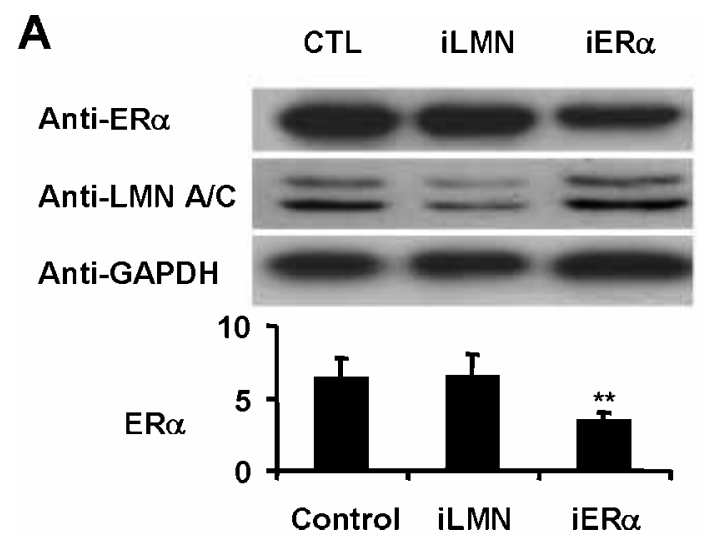

B
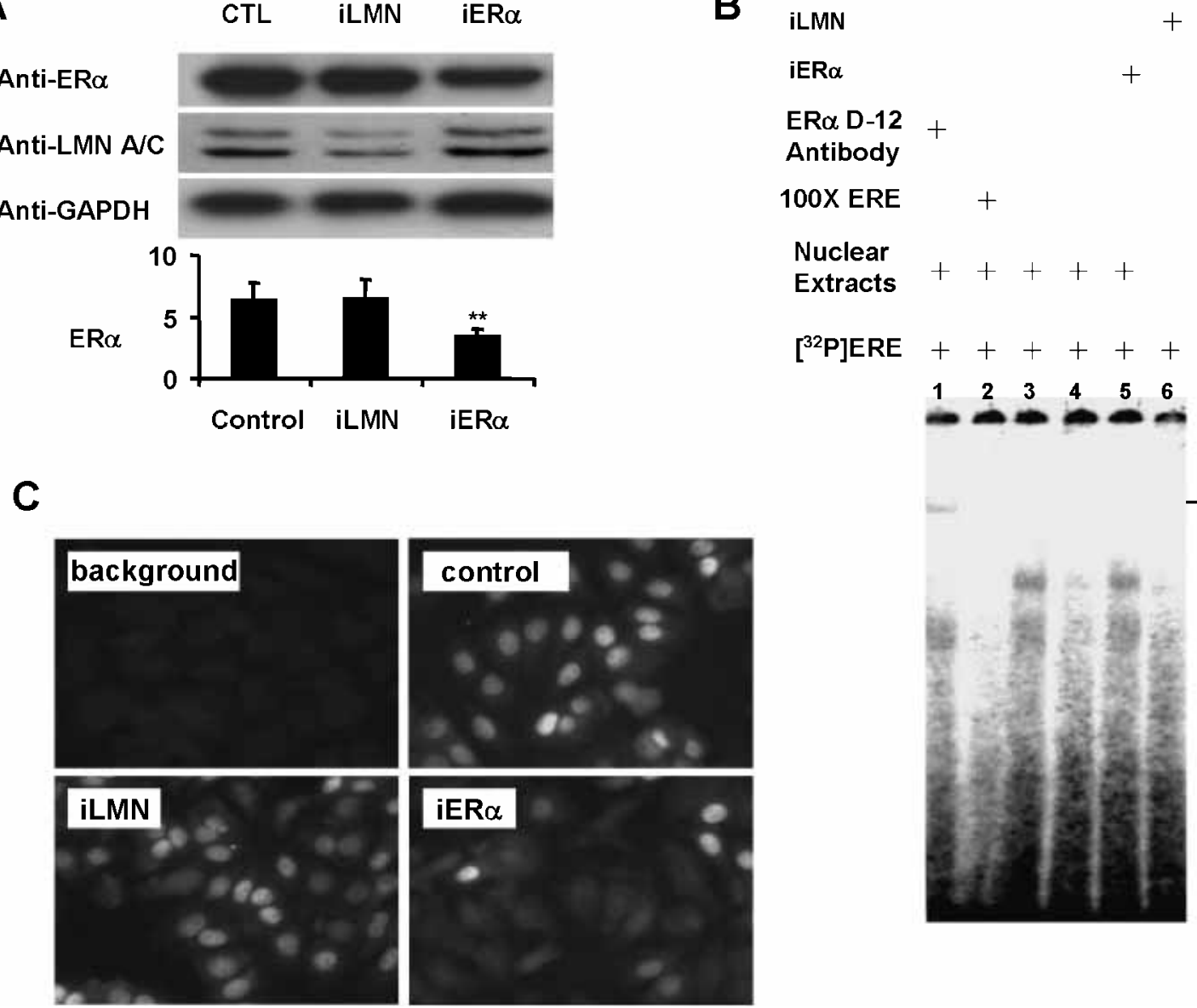

Figure 2 RNA interference with iER $\alpha$. (A) Effects of $\mathrm{iER} \alpha$ on ER $\alpha$ protein expression in MCF-7 cells. Cells were transfected with $\mathrm{iER} \alpha$ and iLMN (as control siRNA), and whole-cell extracts were analyzed for ER $\alpha$, lamin A/C (LMN) and GAPDH proteins by Western blot analysis as described in the Materials and methods section. Results are expressed means \pm S.D. from three replicate determinations for each treatment group, and a significant $(P<0.05)$ decrease in ER $\alpha$ (compared with solvent control or iLMN) protein levels was observed $\left(^{* *}\right)$. CTL, control. (B) Gel mobility shift assay. MCF-7 cells were treated with solvent, iER $\alpha$, or iLMN, and binding of nuclear extracts to [32P]ERE was determined in gel mobility shift assays as described in the Materials and methods section. Specifically bound bands and supershifted complexes are indicated by arrows. (C) Immunocytochemistry. MCF-7 cells were transfected with iER $\alpha$ or iLMN, and stained with ER $\alpha$ or lamin A/C antibodies. Immunofluorescence was determined as described in the Materials and methods section.

iER $\alpha$-mediated decreases in ER $\alpha$ protein is also evident in MCF-7 cells immunostained for ER $\alpha$ (Fig. 2G). Compared with control (untreated) cells or cells transfected with iLMN, ER $\alpha$ protein was significantly decreased in MCF-7 cells transfected with iER $\alpha$.

The specificity of the RNA interference assay was further investigated in MCF-7 cells transfected with an $\mathrm{E}_{2}$-responsive $\mathrm{pC} 3$-luc construct which contains the human complement $\mathrm{C} 3$ gene promoter insert. $\mathrm{E}_{2}-$ induced luciferase activity in cells transfected with pC3-luc and iLMN, whereas hormone-induced activity was decreased in cells transfected with iGL2 (which targets bacterial luciferase) or iER $\alpha$ (Fig. 3A). As a negative control, we show that $\mathrm{iER} \alpha$ does not affect
TCDD-induced transactivation in MCF-7 cells transfected with an aryl hydrocarbon-responsive construct (pDRE $E_{3}$-luc; Fig. 3B). These results are consistent with previous studies showing that IGF-I induced $\mathrm{E}_{2}$ responsive genes through ligand-independent activation of nuclear ER $\alpha$ (Stoica et al. 2000, Wang et al. 2000, Xie et al. 2001). IGF-I also activates MAPK- and PI3-K-dependent pathways including phosphorylationdependent activation of Elk-1 and SRF, which are serum-response element (SRE)-dependent genes (Duan et al. 2001, 2002). Compared with the solvent control, using acetic acid, IGF-I induced transactivation in MCF-7 cells transfected with iLMN, a GAL4-Elk-1 expression plasmid, and a pGAL4 reporter construct 

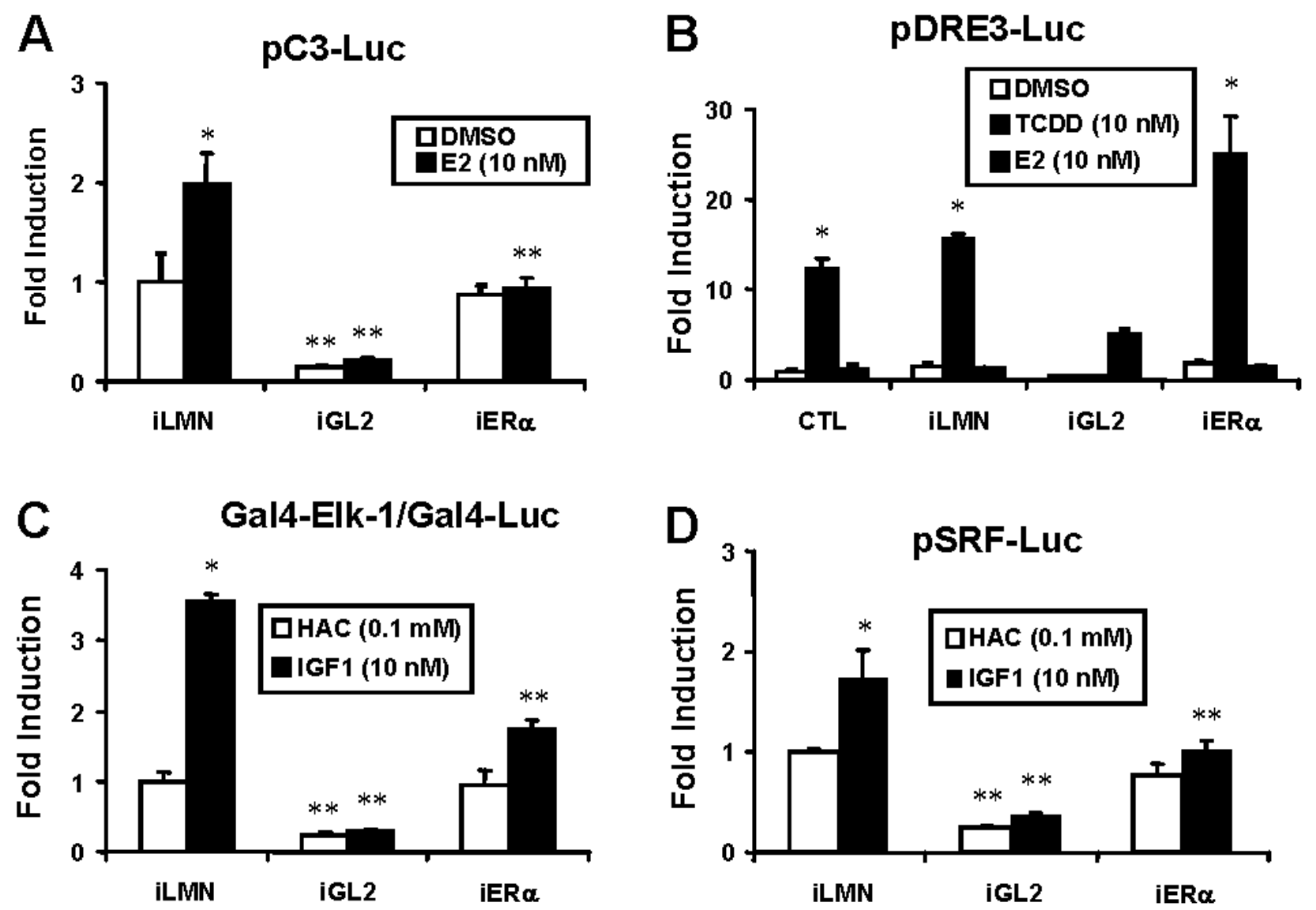

Figure 3 Effects of iER on transactivation in MCF-7 cells transfected with several ligand-activated constructs. Cells were

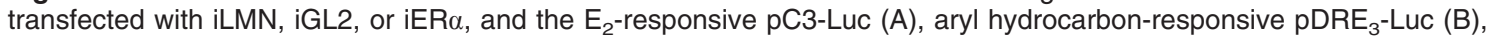
MAPK-regulated Gal4-Elk-1/Gal4-Luc (C), and a PI3-K-regulated pSRF-Luc (D) constructs. Cells were treated with DMSO, 10 nM $\mathrm{E}_{2}, 10 \mathrm{nM}$ TCDD, or $10 \mathrm{nM}$ IGF-I, and luciferase activity was determined as described in the Materials and methods section. Results summarized in $A-D$ are means \pm S.D. from three replicate determinations for each treatment group, and significantly $(P<0.05)$ increased activities (compared with solvent control) are indicated by * and significant inhibition by siRNAs is indicated by **. CTL, control; HAC, acetic acid vehicle.

(Fig. 3C; containing five tandem GAL4-response elements), or an SRF-luc construct (Fig. 3D; containing three tandem SRF motifs). In contrast, activation of both constructs was significantly inhibited by transfection with iGL2 or iER $\alpha$ demonstrating that $\mathrm{ER} \alpha$ plays a role in IGF-I-induced transactivation in MCF-7 cells.

We further investigated the role of $\mathrm{ER} \alpha$ in mediating IGF-I-induced gene expression by investigating phosphorylation of Akt or MAPK (Fig. 4A and B). Figure 4A shows that, compared with untransfected cells or cells transfected with iLMN (a control; Fig. 4A, lanes 1 and 2), iER $\alpha$ significantly decreased ER $\alpha$ protein levels in the presence or absence of IGF-I (Fig. 4A, lanes 3 and 6). IGF-I treatment did not affect levels of ER $\alpha$ protein but induced Akt phosphorylation (Fig. 4A, lanes 4-6); however, in cells cotransfected with $\operatorname{iER} \alpha$ there was a significant decrease in IGF-I-induced Akt phosphoryl- ation. In a separate experiment using a comparable approach, it was also apparent that iER $\alpha$ also decreased MAPK phosphorylation (Fig. 4B), and this was consistent with decreased Elk-1 and SRF activation by IGF-I in cells transfected with iER $\alpha$ (Fig. 3C and D). These results suggest that $\mathrm{ER} \alpha$ is required for activation of MAPK/PI3-K-dependent kinases by IGF-I.

IGF-I-induced signaling in the mouse uterus (Klotz et al. 2002) suggested that activation of PI3-K required IRS-I, whereas activation of MAPK was IRS-Idependent. The results in Fig. 4C show that transfection of iIRS-I in MCF-7 cells decreases IRS-I protein expression but does not significantly decrease phosphorylation of Akt or MAPK. These results suggest that IRS-I is not required for IGF-I-induced activation of PI3-K or MAPK in MCF-7 cells, and differs from the activation pathway in the mouse uterus (Klotz et al. 2002). 
A
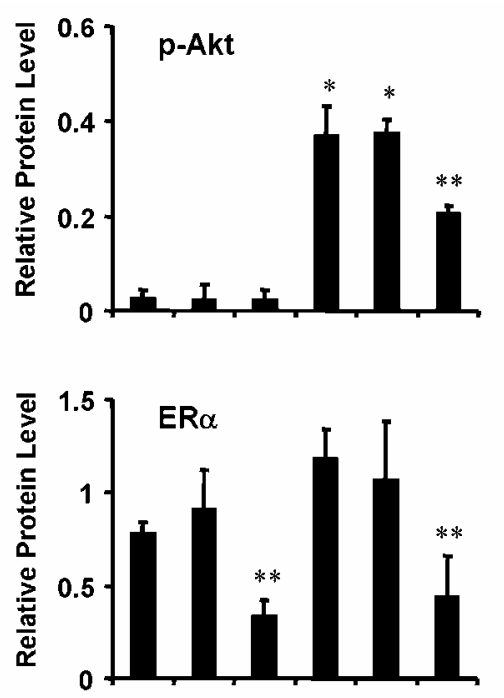

iLMN

$\mathrm{iER} \alpha$

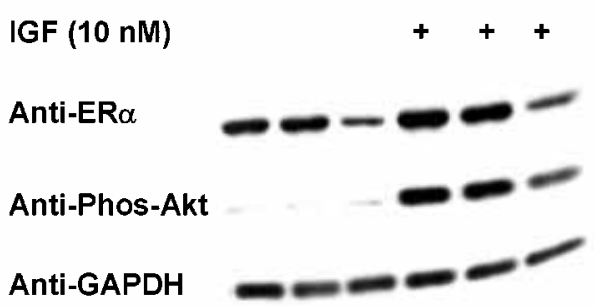

B
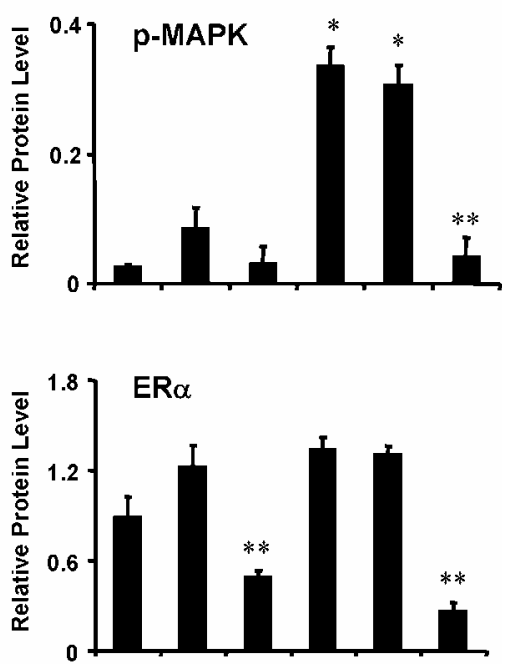

iLMN

$\mathrm{iER} \alpha$

IGF (10 nM)

Anti-ER $\alpha$

Anti-Phos-Erk

Anti-GAPDH

C

Time (min)
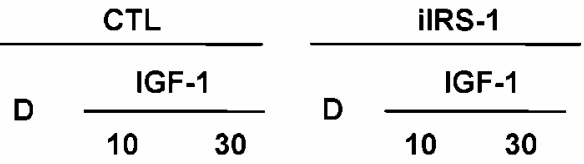

Anti-IRS-1

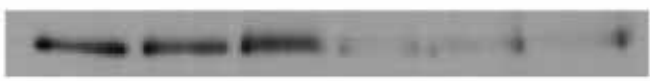

Anti-Phos-Akt

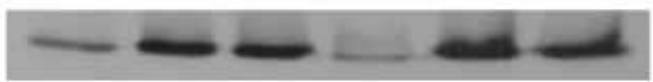

Anti-Phos-Erk

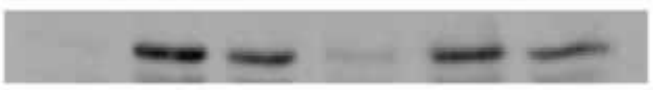

Anti-GAPDH

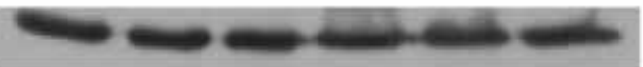

Figure 4 Effects of $\mathrm{iER} \alpha$ and ilRS-I on IGF-I-dependent kinase activation. Effects of $\mathrm{iER} \alpha$ on phosphorylation of Akt (A) and MAPK (B). MCF-7 cells were transfected with siRNAs as described in the Materials and methods section, and phosphoproteins were determined by Western blot analysis of whole-cell lysates. The intensity of the different bands were determined by densitometry and plotted as means \pm S.D. from three replicates in each treatment group. Significant $(P<0.05)$ increases in band intensity (compared with solvent control) are indicated by * and significant inhibition by siRNAs is indicated by **. (C) Effects of ilRS-I on phosphorylation of Akt and MAPK. The experiments were carried essentially as described in (A) and (B) except the phosphorylation levels were determined in DMSO (D; solvent control) and IGF-I-treated cells after treatment for 10 or $30 \mathrm{~min}$. CTL, control. 
A

Control
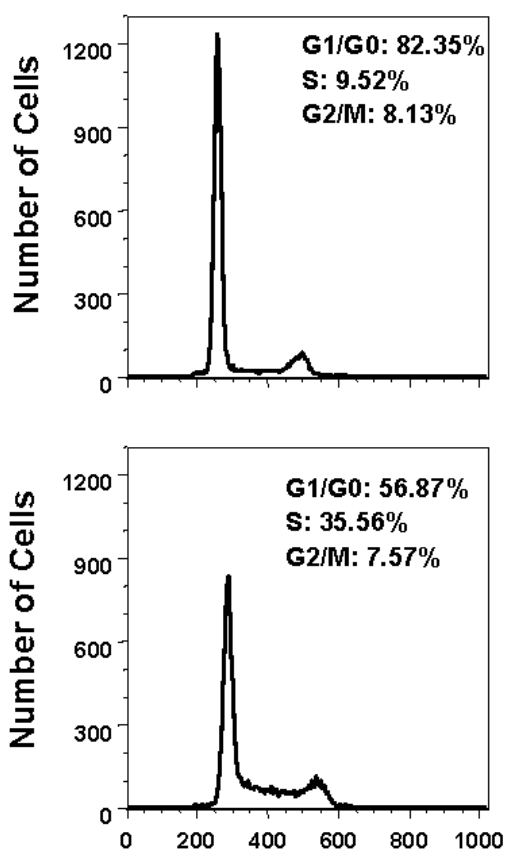

IGF-Treated
iGL2
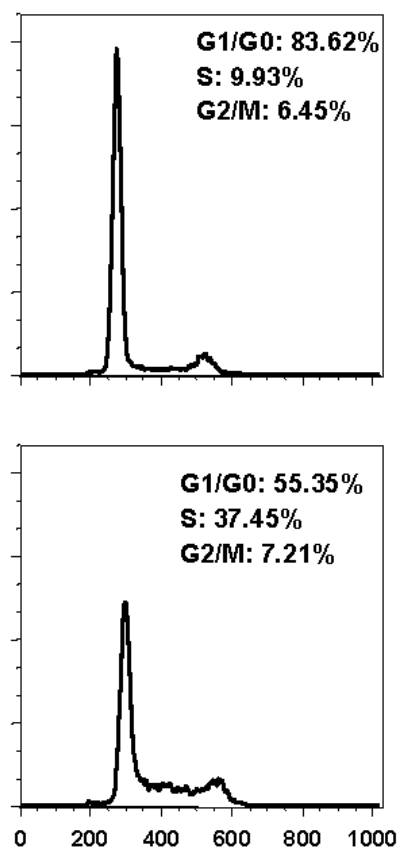

IER $\alpha$
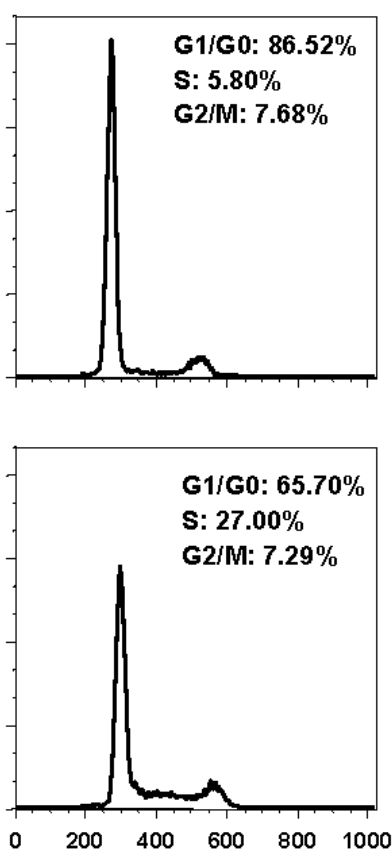

\section{Propidium lodide}

Figure 5 Effects of iER $\alpha$ on IGF-I-induced cell-cycle progression and proliferation in MCF-7 cells. (A) FACS analysis. Serum-starved MCF-7 cells were treated with DMSO or $10 \mathrm{nM}$ IGF-I alone or cotransfected with iGL2 and $\mathrm{iER} \alpha$, and the percentage of distribution of cells in $G_{1} / G_{0}, S$, and $G_{2} / M$ were determined by FACS analysis as described in the Materials and methods section. The results of three separate FACS experiments showed that after transfection with iER $\alpha$ there was a $13.0 \pm 1.44 \%$ increase in $G_{0} / G_{1}$ and a $9.27 \pm 3.47 \%$ decrease in S-phase distribution of the cells. Results are expressed as means \pm S.E. (B) Cell proliferation. MCF-7 cells were transfected with iER $\alpha$ or iGL2 and, after $24 \mathrm{~h}$, cells were treated with $10 \mathrm{nM}$ IGF-I for $48 \mathrm{~h}$, and cell numbers were determined as described in the Materials and methods section. Results are expressed as means \pm S.E. for three replicate determinations for each treatment group, and a significant $(P<0.05)$ decrease in cell number was observed in cells transfected with iER $\alpha$ compared with cells transfected with iGL2.

transfected with iER $\alpha$, there was a further increase in the percentage of cells in $\mathrm{G}_{0} / \mathrm{G}_{1}$ phase $(86 \cdot 5 \%)$ and a decrease of those in $\mathrm{S}$ phase $(5 \cdot 8 \%)$, suggesting that $\mathrm{ER} \alpha$ contributes, in part, to the $\mathrm{G}_{0} / \mathrm{G}_{1}-\mathrm{S}$-phase progression of untreated (control) MCF-7 cells. Treatment of MCF-7 cells with $10 \mathrm{nM}$ IGF-I for $18-20 \mathrm{~h}$ significantly decreased (25-28\%) the percentage of cells in $\mathrm{G}_{0} / \mathrm{G}_{1}$ and a comparable increase in the percentage of cells in $\mathrm{S}$ phase was observed. However, in MCF-7 cells transfected with iER $\alpha$, IGF-I-induced $\mathrm{G}_{1}-\mathrm{S}$-phase 


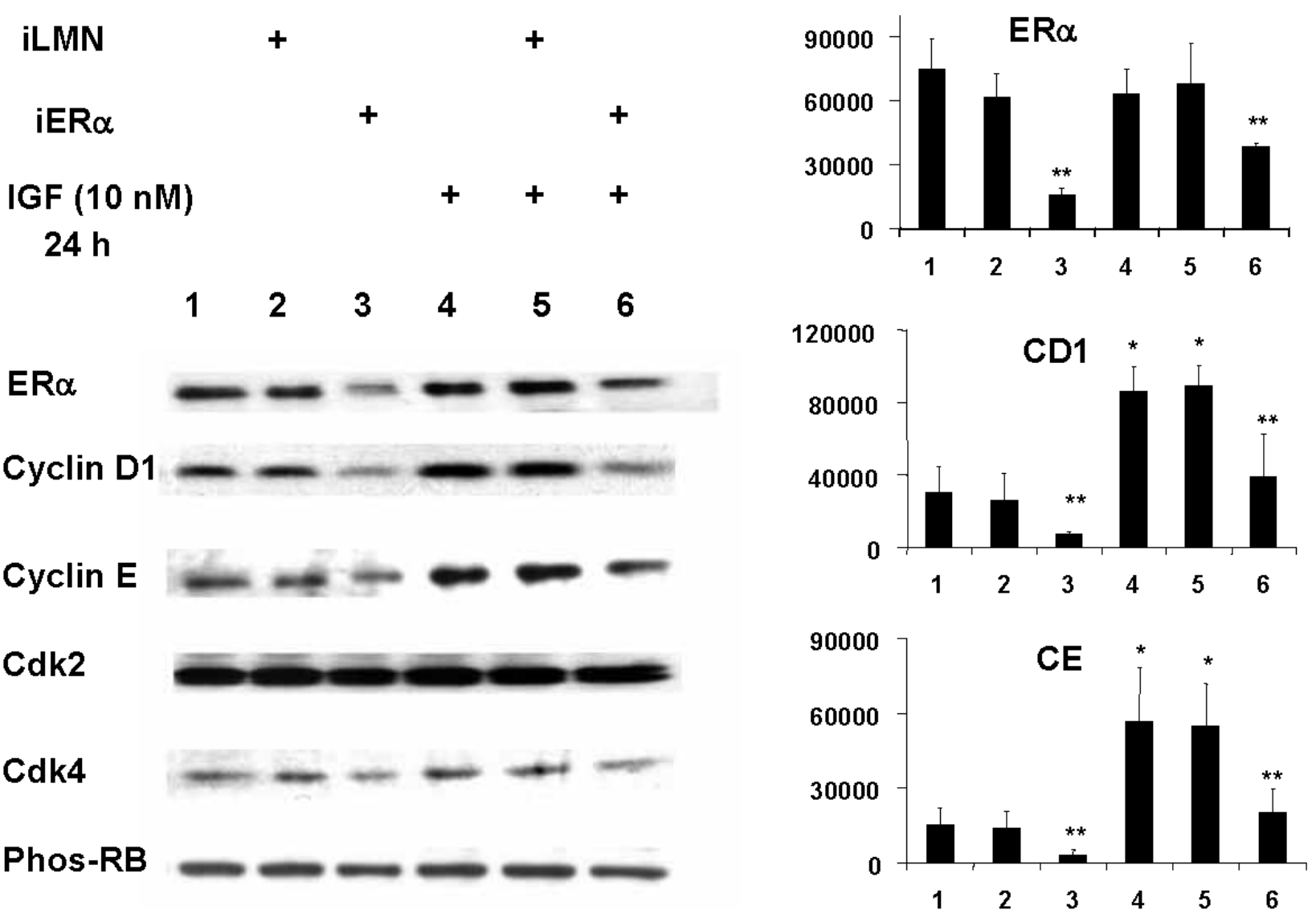

Figure 6 Effects of iER $\alpha$ on IGF-I-induced cell-cycle proteins. MCF-7 cells were transfected with iLMN (as a control siRNA) or iER and treated with either (10 nM) IGF-I or solvent vehicle for $24 \mathrm{~h}$. The expression of cyclin D1 (CD1) and cyclin E (CE) proteins were determined by Western blot analysis as described in the Materials and methods section, and intensities were determined and plotted as means \pm S.D. from three replicate for each treatment group. Significant $(P<0.05)$ increases in band intensities (compared with solvent control) are indicated by * and significant inhibition by siRNA is indicated by ${ }^{* *}$.

progression was partially reversed, demonstrating a role for ER $\alpha$ in mediating IGF-I-dependent effects on this specific phase of the cell cycle. In addition, ER $\alpha$ knockdown in MCF-7 cells decreased IGF-I-induced cell proliferation (Fig. 5B). It is possible that some component of IGF-I-induced $\mathrm{G}_{1}-\mathrm{S}$-phase progression and cell proliferation may be ER $\alpha$-independent.

The potential role of cell-cycle-regulatory proteins associated with ER $\alpha$-dependent actions of IGF-I were further investigated by western blot analysis (Fig. 6). Untreated (Fig. 6, lanes 1-3) and IGF-I-treated (Fig. 6, lanes 4-6) cells were untransfected (Fig. 6, lanes 1 and 4) or transfected with iLMN (Fig. 6, lanes 2 and 4) or iER $\alpha$ (Fig. 6, lanes 3 and 6), and whole-cell lysates were analyzed by western blot analysis. The patterns of ER $\alpha$ expression were similar to those illustrated in Figs 4A and $\mathrm{B}$, and the various treatments did not affect levels of cdk2 or cdk4 or phospho-Rb proteins, and levels of IGF-I receptor were also unchanged (data not shown). In contrast, IGF-I induced cyclin D1 and cyclin E protein levels and cotransfection with iER $\alpha$ decreased induction of both proteins. The results indicate that ER $\alpha$ plays a role in endogenous expression of both cyclin D1 and cyclin $\mathrm{E}$ since levels of these proteins were significantly decreased in untreated cells transfected with iER $\alpha$. These data suggest that induction of cyclin D1 and cyclin $\mathrm{E}$ by IGF-I is an important response associated with $\mathrm{G}_{1}-\mathrm{S}$-phase progression. Previous studies also show that cyclin D1 and cyclin E were induced by IGF-I in MCF-7 cells (Dufourny et al. 1997, Dupont et al. 2000) and this is consistent with the induction of $\mathrm{G}_{1}$-S-phase progression (Fig. 5) which is also dependent, in part, on expression of ER $\alpha$.

\section{Effects of ICI 182780 on IGF-I-induced responses}

A previous study reported that although ICI 182780 inhibited IGF-I-induced growth of MCF-7 cells (Varma \& Conrad 2002), the antiestrogen did not completely 


\section{A Cotreatment for $10 \mathrm{~min}$}

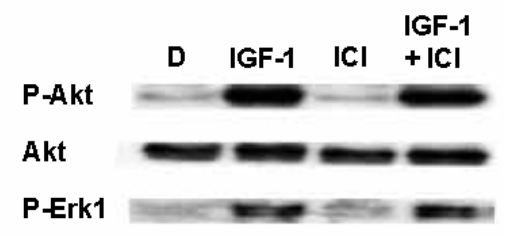

Erk1

B

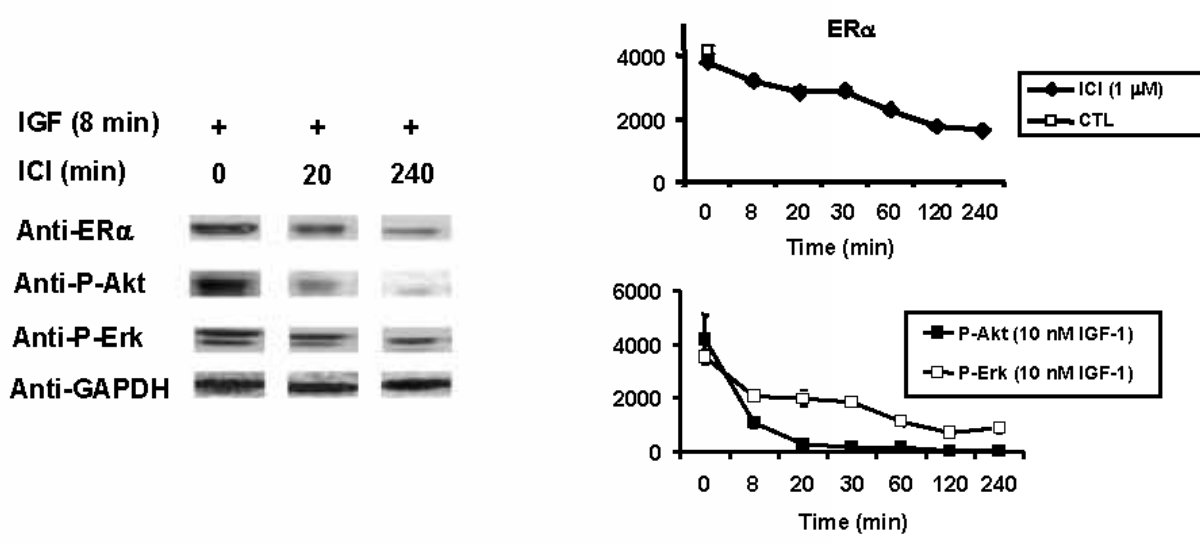

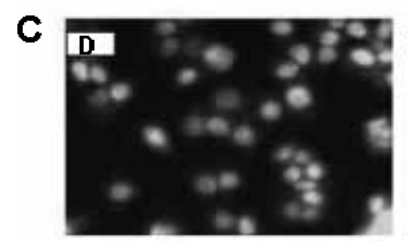
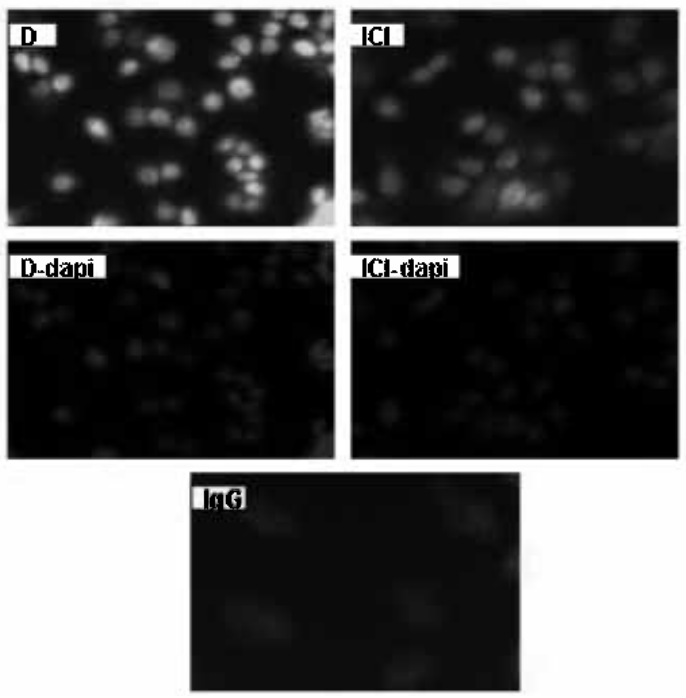

block IGF-I signaling including phosphorylation of Akt and IRS-I or induction of cyclin D1. These results are surprising since ICI 182780 induces proteasomedependent downregulation of $\mathrm{ER} \alpha$ in breast cancer cells (Stenoien et al. 2001, Wijayaratne \& McDonnell 2001, Fan et al. 2003, Wormke et al. 2003). Based on the results obtained in the siRNA knockdown studies with iER $\alpha$ (Figs 2-6), we further investigated the effects of ICI 182780 on IGF-I-induced pathways in MCF-7 cells.
Figure 7 Inhibition of IGF-I-induced responses by ICI 182780. (A) Activation of kinases (short term). Cells were treated with $10 \mathrm{nM}$ IGF-I alone or in combination with $1 \mu \mathrm{M} \mathrm{ICl} 182780$ for $10 \mathrm{~min}$, and whole-cell lysates were analyzed by Western blot analysis for Akt, p-Akt, Erk-1, and pErk-1 as described in the Materials and methods section. (B) Time-dependent inhibition on IGF-I-induced kinases. MCF-7 cells were pretreated with ICI 182780 for different periods of time and then treated with IGF-I for $10 \mathrm{~min}$, and whole-cell lysates were analyzed by Western blot analysis as described in the Materials and methods section. Band intensities were determined by densitometry as described in the Materials and methods section. Each sample was determined in triplicate, and the data shown are from a representative experiment, and expressed in the bar graphs as means \pm S.D.CTL, control. (C) Immunocytochemical analysis of ER $\alpha$. MCF-7 cells were untreated (DMSO; D) or treated with ICI 182780 (ICI) for $2 \mathrm{~h}$, and stained with ER $\alpha$ antibody or IgG. Immunofluorescence was determined as described in the Materials and methods section. DAPI (4,6-diamidino-2-phenylindole) staining was shown to demonstrate nuclear staining.

Results of initial studies showed that cotreatment of MCF-7 cells with $1 \mu \mathrm{M}$ ICI 182780 and $10 \mathrm{nM}$ IGF-I (8 min) only slightly decreased MAPK and Akt phosphorylation (Fig. 7A). Since ICI 182780 induces a time-dependent decrease in levels of ER $\alpha$ (Fan et al. 2003, Stenoien et al. 2001, Wijayaratne \& McDonnell 2001, Wormke et al. 2003), we therefore determined the effects of $1 \mu \mathrm{M}$ ICI 182780 on IGF-I-induced phosphorylation for up to $4 \mathrm{~h}$ after treatment with the 


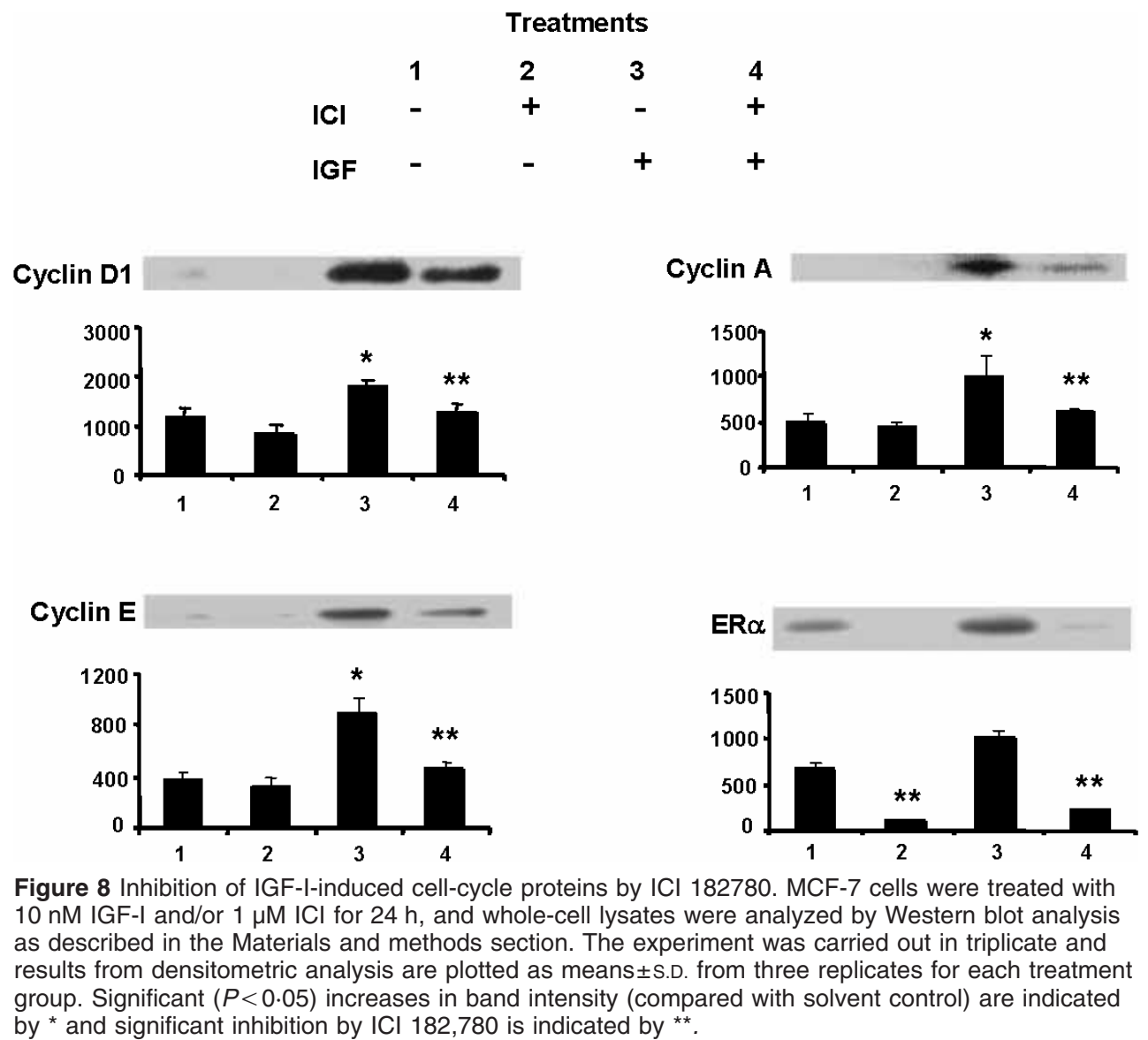

antiestrogen (Fig. 7B). IGF-I (10 min) alone induced phosphorylation of Akt and MAPK. After cotreatment with ICI 182780 for $20 \mathrm{~min}$, there was a significant decrease of $\mathrm{ER} \alpha$ protein, and phosphorylation of Akt and MAPK was also decreased compared to treatment with IGF-I alone. Quantitation of ER $\alpha$ protein levels and kinase phosphorylation in cells cotreated with IGF-I plus ICI 182780 showed a time-dependent decrease in these parameters and decreased Akt phosphorylation was the most pronounced response at the 20-min time point. Decreased ER $\alpha$ protein in MCF-7 cells treated with $1 \mu \mathrm{M}$ ICI 182780 for $2 \mathrm{~h}$ was also confirmed by immunocytochemical analysis (Fig. 7C) and the results were similar to those observed in MCF-7 cells transfected with iER $\alpha$ (Fig. 2C). Moreover, ICI 182780 also inhibited IGF-I-induced transactivation in cells transfected with PI3-K- and MAPK-dependent constructs (data not shown) as observed in MCF-7 cells transfected with iER $\alpha$ (Fig. 3C and D).

The effects of ICI 182780 on induction of cyclins D1, $\mathrm{A}$ and $\mathrm{E}$ by IGF-I were also investigated in MCF-7 cells treated with $10 \mathrm{nM}$ IGF-I $(24 \mathrm{~h}), 1 \mu \mathrm{M}$ ICI 182,780
(24 h), or their combination (Fig. 8). ICI 182780 alone decreased levels of ER $\alpha$ protein but did not significantly affect cyclins D1, A and E, and this was in contrast to the decrease in cyclin D1 and A protein levels in cells transfected with iER $\alpha$ (Fig. 6). This suggests that other activities of ICI 182780 may prevent degradation of these proteins. IGF-I alone induced cyclin D1, A and E proteins; however, in the combined treatment (ICI 182780 plus IGF-I), the antiestrogen significantly inhibited induction of the cyclins by IGF-I. ER $\alpha$ protein was not affected by IGF-I but decreased after combined treatment with ICI 182780. Thus, degradation of ER $\alpha$ by iER $\alpha$ or ICI 182780 is linked to inhibition of IGF-I signaling in MCF- cells, indicating that extranuclear $\mathrm{ER} \alpha$ plays an essential role in IGF-I-induced cell proliferation, cell-cycle progression, MAPK and PI3-K activation and gene expression.

\section{Discussion}

Growth factors play an important role in mammary tumor growth and induce breast cancer cell proliferation 
through both endocrine and paracrine pathways. IGF-I and other polypeptide growth factors interact with their cognate membrane-bound receptors, which have tyrosine kinase activities, and these receptor-ligand interactions initiate activation of kinase cascades and their downstream nuclear genomic targets. Although growth factors induce mitogenic responses and gene expression in cells/tissues that do not express the ER, in $\mathrm{E}_{2}$-responsive cells/tissues growth factor-induced responses are tightly coupled with ER expression. For example, in ER $\alpha$-knockout (ERKO) mice, the effects of EGF and IGF-I are attenuated or suppressed (Curtis et al. 1996, Klotz et al. 2002). EGF induces uterine EGF receptor autophosphorylation and c-Fos expression in ERKO mice, whereas induction of uterine progesterone receptor mRNA and DNA synthesis by EGF were not observed (Curtis et al. 1996, Klotz et al. 2002). IGF-I induces uterine DNA synthesis in wild-type but not ERKO mice; in contrast, IGF-I receptor-dependent activation of PI3-K and MAPK is induced by IGF-I in both wild-type and ERKO mice, suggesting that kinase activation in the absence of $\mathrm{ER} \alpha$ is insufficient for uterine proliferation (Klotz et al. 2002). IGF-I induces proliferation of MCF-7 cells (Fig. 1) and this response is inhibited by antiestrogens. Moreover, IGF-I does not induce growth of an ER $\alpha$-negative MCF-7 cell subline; however, re-expression of $\mathrm{ER} \alpha$ in these cells restores IGF-I responsiveness (Oesterreich et al. 2001).

One level of IGF-ER $\alpha$ crosstalk involves ligandindependent activation of $\mathrm{E}_{2}$-responsive genes through selective phosphorylation of ER $\alpha$ (Ali et al. 1993, Kato et al. 1995, Bunone et al. 1996, Ignar-Trowbridge et al. 1996, Joel et al. 1998). This pathway involves genomic or nuclear pathways of ER $\alpha$ action in which growth factor-dependent phosphorylation of the receptor is sufficient for induction of genes that require nuclear ER $\alpha$-DNA (promoter) or ER $\alpha$-protein-DNA interactions (Cavailles et al. 1989, Wakeling et al. 1989, Katzenellenbogen \& Norman 1990, Chalbos et al. 1993, Ignar-Trowbridge et al. 1993, Westley \& May 1994, Wang et al. 2000, Xie et al. 2001). IGF-I-induced responses may also involve extranuclear ER $\alpha$ which associates with several key proteins involved in kinase pathways, including the IGF-IR, p85 $\alpha$ (PI3-K regulatory subunit), G proteins, Src, and Shc (Kahlert et al. 2000, Migliaccio et al. 2000, Simoncini et al. 2000, Sun et al. 2001, Wyckoff et al. 2001, Razandi et al. 2002, Song et al. 2002). Inhibition of IGF-I-induced cell proliferation by ICI 182780 and LY294002 (Fig. 1) implies that both $\mathrm{ER} \alpha$ and PI3-K are necessary for this response. The role of ER $\alpha$ in mediating IGF-I-induced gene expression, kinase activation, and cell-cycle progression was extensively investigated using $\mathrm{iER} \alpha$ to efficiently knockdown ER $\alpha$ protein (Fig. 2). This approach could then be used to demonstrate that $\mathrm{ER} \alpha$ was required for IGF-I-dependent activation of MAPK and PI3-K signaling pathways (Fig. 4) and subsequent transactivation of SRE- and SRF-dependent promoter-reporter constructs (Fig. 3). These results are in contrast to the effects of IGF-I in the uterus of wild-type and ERKO mice where both Akt and MAPK are phosphorylated after treatment with IGF-I (Klotz et al. 2002). This report (Klotz et al. 2002) also suggested that IRS-I may be important for IGF-I-induced activation of PI3-K, and another study demonstrated that re-expression of ER $\alpha$ in ER-negative MCF-7 cells not only restored IGF-I responsiveness but was accompanied by increased expression of IRS-I and IGF-IR (Ignar-Trowbridge et al. 1996). However, using iIRS-I to knockdown the protein (Fig. 4C) it was apparent that induction of MAPK and Akt phosphorylation by IGF-I were unaffected, whereas knockdown of ER $\alpha$ clearly decreased kinase-dependent phosphorylation (Fig. 4A and B). Thus, although IRS-I is an important signaling molecule activated by IGF-I in MCF-7 cells (Nolan et al. 1997, Jackson et al. 1998, Lee et al. 1999), our results suggest that IRS-I does not directly regulate IGF-I-dependent activation of MAPK or PI3-K.

The critical role of ER $\alpha$ in mediating the mitogenic activity of IGF-I in MCF-7 cells was also confirmed in ER $\alpha$-knockdown experiments, which demonstrated that IGF-I-induced $\mathrm{G}_{1}$-S-phase progression and cell proliferation (Fig. 5) and cyclin D1 and E protein expression were dependent on ER $\alpha$ (Fig. 6). While these results were consistent with previous reports on the mitogenic activity of IGF-I (Dufourny et al. 1997, Dupont et al. 2000), these data are in contrast to a study showing that ICI 182780 inhibited IGF-dependent growth of MCF-7 cells but not IGF-I-dependent kinase activation (Varma \& Conrad 2002). For example, ICI 182780 did not inhibit IRS-I, MAPK, or Akt phosphorylation or cyclin D1 induction in MCF-7 cells treated with $10 \mathrm{nM}$ IGF-I (Varma \& Conrad 2002). These results are surprising since ICI 182780 induces proteasome-dependent downregulation of ER $\alpha$ in MCF-7 cells (Wijayaratne \& McDonnell 2001, Fan et al. 2003, Wormke et al. 2003) and RNA-interference studies (Figs 2-6) clearly demonstrate an essential role for ER $\alpha$ in IGF-I signaling. Moreover, Lee and coworkers (1999) also reported that ICI 182780 inhibited IGF-I-induced phosphorylation of MAPK, IRS-I, and IGF-IR. We therefore further investigated the time-dependent effects of ICI 182780 on IGF-I-induced activation of kinases, and cyclins (Figs 7 and 8). Preliminary studies showed that short-term cotreatment of MCF-7 cells with IGF-I plus ICI 182780 did not decrease IGF-I-induced phosphorylation of MAPK or PI3-K (Fig. 7A) as previously reported (Varma \& Conrad 2002). However, longer-term studies with ICI 182780 showed that the inhibitory effects of ICI 182780 were time-dependent. The results clearly show that ICI 182780 inhibits IGF-I-induced cyclin D1, E, and A protein expression (Fig. 8), and this was 
paralleled by inhibition of IGF-I induced phosphorylation of Akt and MAPK (Fig. 7B) and IRS-I (data not shown). These data, coupled with ICI 182780-induced degradation of $\mathrm{ER} \alpha$ (with or without IGF-I; Fig. 7B and G), complement the results of RNA-interference studies with $\mathrm{IER} \alpha$ showing that IGF-I action in MCF-7 cells is dependent on crosstalk with extranuclear ER $\alpha$ (Figs 2-6). Although ICI 182780 did not inhibit some IGF-I-induced cell-cycle proteins or Akt/MAPK phosphorylation in the study by Varma and Conrad (2002), they reported that proliferation of MCF-7 cells induced by IGF-I was inhibited by ICI and this corresponded to results of this study (Fig. 1). It was also shown that although ICI 182780 did not affect IGF-I-induced cyclin D1 protein, the antiestrogen inhibited growth factordependent upregulation of both cyclin D1 mRNA and cyclin A protein levels (Varma \& Conrad 2002), and the latter response was also observed in this study (Fig. 8). The remaining differences between our results and the previous study could also be due to variations in MCF-7 cell passage and origin, serum lot, and the different concentrations of ICI $182780(1 \mu \mathrm{M}$ (this study) versus $100 \mathrm{nM}$ (Varma \& Conrad 2002)).

In summary, results from this study demonstrate the important role of $\mathrm{ER} \alpha$ in mediating the mitogenic activity of IGF-I in MCF-7 cells and demonstrate that there were clear differences between the mechanisms of IGF-I-induced signaling in breast cancer cells and in the mouse uterus (Klotz et al. 2002). Both $\mathrm{E}_{2}$ and IGF-I induce many comparable responses in MCF-7 and other breast cancer cell lines, and the activities of both mitogens are ER-dependent. However, there are also mechanistic differences in the actions of $\mathrm{E}_{2}$ and IGF-I. For example, IGF-I-induced activation of an SRE (PI3-K/MAPK) was inhibited by the H1356 polypeptide, which is an IGF-I receptor antagonist, whereas $\mathrm{E}_{2}$-induced activation of this promoter was unaffected (Duan et al. 2001, 2002). A recent study showed that $\mathrm{E}_{2}$-induced formation of an ER $\alpha$-Shc-IGF-IR complex in MCF-7 cells, whereas treatment with IGF-I did not recruit ER $\alpha$ to this complex (Song et al. 2004). Current studies are focused on further delineating the mechanisms of IGF-I/ $\mathrm{E}_{2}$-induced responses in breast cancer cells and determining the differential role of $\mathrm{ER} \alpha$ and its interactions with extranuclear factors.

\section{Acknowledgements}

Financial support from the National Institutes of Health (ES09106 and ES09253), the Texas Agricultural Experiment Station, and the Sid Kyle endowment are gratefully acknowledged. The authors declare that there is no conflict of interest that would prejudice the impartiality of this scientific work.

\section{References}

Ali S, Metzger D, Bornert JM \& Chambon P 1993 Modulation of transcriptional activation by ligand-dependent phosphorylation of the human oestrogen receptor A/B region. EMBO Fournal 12 $1153-1160$.

Bradford MM 1976 A rapid and sensitive method for the quantitation of microgram quantities of protein utilizing the principle of protein-dye binding. Analytical Biochemistry 72 248-254.

Bunone G, Briand PA, Miksicek RJ \& Picard D 1996 Activation of the unliganded estrogen receptor by EGF involves the MAP kinase pathway and direct phosphorylation. EMBO fournal $\mathbf{1 5}$ 2174-2183.

Castro-Rivera E, Samudio I \& Safe S 2001 Estrogen regulation of cyclin D1 gene expression in ZR-75 breast cancer cells involves multiple enhancer elements. Fournal of Biological Chemistry 276 30853-30861.

Cavailles V, Garcia M \& Rochefort H 1989 Regulation of cathepsin $\mathrm{D}$ and $\mathrm{pS} 2$ gene expression by growth factors in MCF-7 human breast cancer cells. Molecular Endocrinology 3 552-558.

Chalbos D, Philips A, Galtier F \& Rochefort H 1993 Synthetic antiestrogens modulate induction of $\mathrm{pS} 2$ and cathepsin-D messenger ribonucleic acid by growth factors and adenosine 3',5'-monophosphate in MCF7 cells. Endocrinology 133 571-576.

Chan JM, Stampfer MJ, Giovannucci E, Gann PH, Ma J, Wilkinson P, Hennekens CH \& Pollak M 1998 Plasma insulin-like growth factor-I and prostate cancer risk: a prospective study. Science $\mathbf{2 7 9}$ 563-566.

Cohen P 1998 Serum insulin-like growth factor-I levels and prostate cancer risk-interpreting the evidence. Fournal of the National Cancer Institute 90 876-879.

Curtis SW, Washburn T, Sewall C, DiAugustine R, Lindzey J, Couse JF \& Korach KS 1996 Physiological coupling of growth factor and steroid receptor signaling pathways: estrogen receptor knockout mice lack estrogen- like response to epidermal growth factor. PNAS 93 12626-12630.

Dickson RB \& Lippman ME 1995 Growth factors in breast cancer. Endocrine Reviews 16 559-589.

Duan R, Xie W, Burghardt R \& Safe S 2001 Estrogen receptormediated activation of the serum response element in MCF-7 cells through MAPK-dependent phosphorylation of Elk-1. Fournal of Biological Chemistry 276 11590-11598.

Duan R, Xie W, Li X, McDougal A \& Safe S 2002 Estrogen regulation of c-fos gene expression through phosphatidylinositol-3kinase-dependent activation of serum response factor in MCF-7 breast cancer cells. Biochemistry and Biophysical Research Communications 294 384-394.

Dufourny B, Alblas J, van Teeffelen HA, van Schaik FM, Van der Burg B, Steenbergh PH \& Sussenbach JS 1997 Mitogenic signaling of insulin-like growth factor I in MCF-7 human breast cancer cells requires phosphatidylinositol 3-kinase and is independent of mitogen-activated protein kinase. Fournal of Biological Chemistry 272 31163-31171.

Dupont J, Karas M \& LeRoith D 2000 The potentiation of estrogen on insulin-like growth factor I action in MCF-7 human breast cancer cells includes cell cycle components. Fournal of Biological Chemistry 275 35893-35901.

Fan M, Bigsby RM \& Nephew KP 2003 The NEDD8 pathway is required for proteasome-mediated degradation of human estrogen receptor (ER)- $\alpha$ and essential for the antiproliferative activity of ICI 182,780 in ER $\alpha$-positive breast cancer cells. Molecular Endocrinology 17 356-365.

Grimberg A \& Cohen P 2000 Role of insulin-like growth factors and their binding proteins in growth control and carcinogenesis. fournal of Cell Physiology 183 1-9.

Gullick WJ, Bianco C, Normanno N, Martinez-Lacaci I, De Santis M, Ebert AD \& Salomon DS 1998 Growth factors and their receptors. Women and Cancer $\mathbf{1}$ 29-57. 
Ignar-Trowbridge DM, Teng CT, Ross MJ, Parker MG, Korach KS \& McLachlan JA 1993 Peptide growth factors elicit estrogen receptor-dependent transcriptional activation of an estrogenresponsive element. Molecular Endocrinology 7 992-998.

Ignar-Trowbridge DM, Pimentel M, Parker MG, McLachlan JA \& Korach KS 1996 Peptide growth factor cross-talk with the estrogen receptor requires the $\mathrm{A} / \mathrm{B}$ domain and occurs independently of protein kinase $\mathrm{C}$ or estradiol. Endocrinology 137 $1735-1744$.

Jackson JG, White MF \& Yee D 1998 Insulin receptor substrate-1 is the predominant signaling molecule activated by insulin-like growth factor-I, insulin, and interleukin-4 in estrogen receptorpositive human breast cancer cells. Fournal of Biological Chemistry 273 9994-10003.

Joel PB, Smith J, Sturgill TW, Fisher TL, Blenis J \& Lannigan DA 1998 pp90 ${ }^{\text {rsk1 }}$ regulates estrogen receptor-mediated transcription through phosphorylation of Ser-167. Molecular and Cellular Biology 18 1978-1984.

Kahlert S, Nuedling S, Van Eickels M, Vetter H, Meyer R \& Grohe C 2000 Estrogen receptor $\alpha$ rapidly activates the IGF-1 receptor pathway. Fournal of Biological Chemistry 275 18447-18453.

Kato S, Endoh H, Masuhiro Y, Kitamoto T, Uchiyama S, Sasaki H, Masushige S, Gotoh Y, Nishida E \& Kawashima H 1995 Activation of the estrogen receptor through phosphorylation by mitogen-activated protein kinase. Science 270 1491-1494.

Kato S, Masuhiro Y, Watanabe M, Kobayashi Y, Takeyama KI, Endoh H \& Yanagisawa J 2000 Molecular mechanism of a cross-talk between oestrogen and growth factor signalling pathways. Genes to Cells 5 593-601.

Katzenellenbogen BS \& Norman MJ 1990 Multihormonal regulation of the progesterone receptor in human breast cancer cells: interrelationships among insulin/insulin- like growth factor-I, serum and estrogen. Endocrinology 126 891-898.

Klotz DM, Hewitt SC, Ciana P, Raviscioni M, Lindzey JK, Foley J, Maggi A, DiAugustine RP \& Korach KS 2002 Requirement of estrogen receptor-alpha in insulin-like growth factor-1 (IGF-1)-induced uterine responses and in vivo evidence for IGF-1/estrogen receptor cross-talk. Fournal of Biological Chemistry 277 8531-8537.

Lee AV, Jackson JG, Gooch JL, Hilsenbeck SG, CoronadoHeinsohn E, Osborne CK \& Yee D 1999 Enhancement of insulin-like growth factor signaling in human breast cancer: estrogen regulation of insulin receptor substrate-1 expression in vitro and in vivo. Molecular Endocrinology 13 787-796.

Levin ER 2002 Cellular functions of plasma membrane estrogen receptors. Steroids $67471-475$.

Luconi M, Forti G \& Baldi E 2002 Genomic and nongenomic effects of estrogens: molecular mechanisms of action and clinical implications for male reproduction. Fournal of Steroid Biochemisty and Molecular Biology 80 369-381.

Ma J, Pollak MN, Giovannucci E, Chan JM, Tao Y, Hennekens CH \& Stampfer MJ 1999 Prospective study of colorectal cancer risk in men and plasma levels of insulin-like growth factor (IGF)-I and IGF-binding protein-3. Fournal of the National Cancer Institute 91 620-625.

Martin MB, Franke TF, Stoica GE, Chambon P, Katzenellenbogen BS, Stoica BA, McLemore MS, Olivo SE \& Stoica A 2000 A role for Akt in mediating the estrogenic functions of epidermal growth factor and insulin-like growth factor I. Endocrinology 141 4503-4511.

Migliaccio A, Castoria G, Di Domenico M, de Falco A, Bilancio A, Lombardi M, Barone MV, Ametrano D, Zannini MS, Abbondanza C \& Auricchio F 2000 Steroid-induced androgen receptor-oestradiol receptor $\beta$-Src complex triggers prostate cancer cell proliferation. EMBO fournal $195406-5417$.

Ngwenya S \& Safe S 2003 Cell context-dependent differences in the induction of E2F-1 gene expression by $17 \beta$-estradiol in MCF-7 and ZR-75 cells. Endocrinology 144 1675-1685.
Nolan MK, Jankowska L, Prisco M, Xu S, Guvakova MA \& Surmacz E 1997 Differential roles of IRS-1 and SHC signaling pathways in breast cancer cells. International Fournal of Cancer $\mathbf{7 2}$ 828-834.

Oesterreich S, Zhang P, Guler RL, Sun X, Curran EM, Welshons WV, Osborne CK \& Lee AV 2001 Re-expression of estrogen receptor $\alpha$ in estrogen receptor $\alpha$-negative MCF-7 cells restores both estrogen and insulin-like growth factor-mediated signaling and growth. Cancer Research $615771-5777$.

Qin C, Nguyen T, Stewart J, Samudio I, Burghardt R \& Safe S 2002 Estrogen upregulation of $p 53$ gene expression in MCF-7 breast cancer cells is mediated by calmodulin kinase IV-dependent activation of an NFkB/CTF-1 complex. Molecular Endocrinology 16 1793-1809.

Razandi M, Oh P, Pedram A, Schnitzer J \& Levin ER 2002 ERs associate with and regulate the production of caveolin: implications for signaling and cellular actions. Molecular Endocrinology 16 100-115.

Segars JH \& Driggers PH 2002 Estrogen action and cytoplasmic signaling cascades. Part I: membrane-associated signaling complexes. Trends in Endocrinology and Metabolism 13 349-354.

Simoncini T, Hafezl-Moghadam A, Brazil DP, Ley K, Chin, WW \& Liao JK 2000 Interaction of oestrogen receptor with the regulatory subunit of phosphatidylinositol-3-OH kinase. Nature $\mathbf{4 0 7}$ $538-541$.

Singh P 2000 Insulin-like growth factor system in growth, development and carcinogenesis. Fournal of Clinical Ligand Assay 23 214-232.

Smith CL 1998 Cross-talk between peptide growth factor and estrogen receptor signaling pathways. Biology of Reproduction $\mathbf{5 8}$ 627-632.

Song RX, McPherson RA, Adam L, Bao Y, Shupnik M, Kumar R \& Santen RJ 2002 Linkage of rapid estrogen action to MAPK activation by ER $\alpha$-Shc association and She pathway activation. Molecular Endocrinology 16 116-127.

Song RX, Barnes CJ, Zhang Z, Bao Y, Kumar R \& Santen RJ 2004 The role of Shc and insulin-like growth factor 1 receptor in mediating the translocation of estrogen receptor $\alpha$ to the plasma membrane. PNAS 101 2076-2081.

Stenoien DL, Patel K, Mancini MG, Dutertre M, Smith CL, O'Malley BW \& Mancini MA 2001 FRAP reveals that mobility of oestrogen receptor- $\alpha$ is ligand- and proteasome-dependent. Nature Cell Biology 3 15-23.

Stoica A, Saceda M, Fakhro A, Joyner M \& Martin MB 2000 Role of insulin-like growth factor-I in regulating estrogen receptor- $\alpha$ gene expression. Fournal of Cellular Biochemistry $\mathbf{7 6}$ 605-614.

Sun M, Paciga JE, Feldman RI, Yuan Z-Q, Coppola D, Lu YY, Shelley SA, Nicosia SV \& Cheng JQ 2001

Phosphatidylinositol-3-OH kinase (PI3K)/AKT2, activated in breast cancer, regulates and is induced by estrogen receptor $\alpha$ $(\mathrm{ER} \alpha)$ via interaction between ER $\alpha$ and PI3K. Cancer Research 61 5985-5991.

Varma H \& Conrad SE 2002 Antiestrogen ICI 182,780 decreases proliferation of insulin-like growth factor I (IGF-I)-treated MCF-7 cells without inhibiting IGF-I signaling. Cancer Research 62 3985-3991.

Wakeling AE, Newboult E \& Peters SW 1989 Effects of antioestrogens on the proliferation of MCF-7 human breast cancer cells. Fournal of Molecular Endocrinology 2 225-234.

Wang F, Duan R, Chirgwin J \& Safe S 2000 Transcriptional activation of cathepsin D gene expression by growth factors. Fournal of Molecular Endocrinology 24 193-202.

Watson CS, Gametchu B, Norfleet AM, Campbel CH \& Thomas ML 1998 Rapid, nongenomic actions of estrogens. Women and Cancer 1 21-28.

Watson CS, Campbell CH \& Gametchu B 2002 The dynamic and elusive membrane estrogen receptor- $\alpha$. Steroids 67 429-437. 
Weigel NL \& Zhang Y 1998 Ligand-independent activation of steroid hormone receptors. Fournal of Molecular Medicine $\mathbf{7 6}$ 469-479.

Westley BR \& May FEB 1994 Role of insulin-like growth factors in steroid-modulated proliferation. Fournal of Steroid Biochemisty and Molecular Biology 51 1-9.

Wijayaratne AL \& McDonnell DP 2001 The human estrogen receptor- $\alpha$ is a ubiquitinated protein whose stability is affected differentially by agonists, antagonists, and selective estrogen receptor modulators. Fournal of Biological Chemistry 276 35684-35692.

Wolk A, Mantzoros CS, Andersson SO, Bergstrom R, Signorello LB, Lagiou P, Adami HO \& Trichopoulos D 1998 Insulin-like growth factor 1 and prostate cancer risk: a population-based, case-control study. Fournal of the National Cancer Institute 90 911-915.

Wormke M, Stoner M, Saville B, Walker K, Abdelrahim M, Burghardt R \& Safe S 2003 The aryl hydrocarbon receptor mediates degradation of the estrogen receptor $\alpha$ through activation of proteasomes. Molecular and Cellular Biology $\mathbf{2 3}$ $1843-1855$.

Wyckoff MH, Chambliss KL, Mineo C, Yuhanna IS, Mendelsohn ME, Mumby SM \& Shaul PW 2001 Plasma membrane estrogen receptors are coupled to endothelial nitric-oxide synthase through $\mathrm{G \alpha}_{\mathrm{i}}$. Fournal of Biological Chemistry $27627071-27076$.

Xie W, Duan R \& Safe S 2001 Activation of adenosine deaminase in MCF-7 cells through insulin-like growth factor-estrogen receptor $\alpha$ crosstalk. Fournal of Molecular Endocrinology 26 217-228.

Yee D \& Lee AV 2000 Crosstalk between the insulin-like growth factors and estrogens in breast cancer. Fournal of Mammary Gland Biology and Neoplasia 5 107-115.

Received 11 July 2005

Accepted 12 August 2005 